\title{
Rasio Keuangan Kinerja Bank Konvensional yang Terdaftar di Bursa Efek Indonesia
}

\author{
Gustina Hidayat \\ Sekolah Tinggi Ilmu Ekonomi Sebelas April \\ gustina.gustin@yahoo.com
}

\begin{abstract}
ABSTRAK
Kinerja bank dapat memberikan gambaran presentasi yang dicapai bank dalam operasionalnya, yang mana menggambarkan kondisi kesehatan keuangan perusahaan dengan indikator kecukupan modal, likuiditas dan profitabilitas. Dampak pandemi Covid-19 terhadap kinerja sektor perbankan, sungguh besar, nasabah yang akan bertransaksi dialihkan melalui $m$-banking, nasabah yang menerima kucuran kredit dari bank, tidak mampu membayar cicilan pokok dan bunganya, dalam arti menjadi kredit macet. Analisis kinerja keuangan Bank yang mengalami penurunan paling besar, sehingga analisis kesehatan bank menjadi faktor utama bagi para investor, nasabah. Setelah melakukan uji kriteria awal, dalam penelitian ini akan menggunakan empat objek penelitian pada PT. Bank Negara Indonesia, Tbk PT Bank Mandiri, Tbk PT Bank CIMB Niaga, Tbk dan PT Bank BCA, Tbk untuk menganalisis rasio keuangan bank pada periode 2015- 2020. Secara keseluruhan analisis kinerja keuangan menggunakan model RGEC dengan nilai rerata setiap rasionya dinyatakan dalam keadaan sehat, membuktikan bahwa Bank BNI, Bank Mandiri, Bank CIMB Niaga dan Bank BCA pada periode 2015-2019 berada pada predikat keadaan baik.
\end{abstract}

Kata Kunci: Bank Konvensional, Kesehatan Bank, Model RGEC

\begin{abstract}
The bank's performance can provide an overview of the presentation achieved by the bank in its operations, which describes the financial health condition of the company with indicators of capital adequacy, liquidity and profitability. The impact of the Covid-19 pandemic on the performance of the banking sector is, really large, customers who will witness being redirected through $\mathrm{m}^{-}$ banking, customers who receive credit disbursements from banks, unable to pay principal and interest installments, in the sense of being bad credit. Analysis of the Bank's financial performance which experienced the most decrease, so that the bank's health analysts become the main factor for investors, customers. After conducting the initial criteria test, in this study will use four research objects on PT. Bank Negara Indonesia, Tbk PT Bank Mandiri, Tbk PT Bank CIMB Niaga, Tbk and PT Bank BCA, Tbk to analyze the bank's financial ratio in the period 2015-2020.Overall, financial performance analysis using the RGEC model with the average value of each ratio is stated in a healthy state, proving that Bank BNI, Bank Mandiri, Bank CIMB Niaga and Bank BCA in the period 2015-2019 are in a good condition.
\end{abstract}

Keywords: Conventional Bank, Bank Health, RGEC Model

\section{PENDAHULUAN}

Pandemi Covid-19 membawa guncangan bagi perekonomian dan pasar keuangan global sehingga menekan kinerja sektor riil dan meningkatnya pengangguran. Pandemi ini juga berdampak pada meningkatnya beberapa potensi risiko baik risiko likuiditas maupun kredit yang dapat mengancam stabilitas sistem keuangan. Industri manufaktur tidak dapat beroperasi pada kapasitas optimal yang mengakibatkan melonjaknya tingkat pengangguran.

Stabilitas Keuangan merupakan sistem kendali nasional yang dapat dilakukan oleh suatu Negara yang bertujuan untuk mengalokasikan sumber pembiayaan dapat berkontribusi pada pertumbuhan perekonomian nasional. Bank merupakan Lembaga pemegang otoritas moneter serta pembayaran dan pengawasan makroprudensial terhadap sistem keuangan yang terdiri atas lembaga keuangan, perusahaan non keuangan, rumah tangga, pasar keuangan, serta infrastruktur keuangan yang saling berinteraksi dalam pendanaan dan/atau penyediaan pembiayaan pertumbuhan perekonomian. Sistem pembayaran yang bermasalah pada akhirnya dapat menyebabkan instabilitas sistem keuangan, begitu pula gejolak sistem keuangan dapat menghambat kelancaran sistem pembayaran. Keterkaitan inilah yang melatarbelakangi kepentingan Bank Indonesia untuk selalu berupaya menjaga SSK di Indonesia. 
Wakil Direktur Utama Bank Direktur Bank Mandiri Hery Gunardi mengatakan, pada awal 2020, pertumbuhan bisnis agak lambat akibat banyak faktor yakni virus corona hingga juga pertumbuhan ekonomi global yang mengalami perlambatan. Dari sejumlah faktor tersebut, perlambatan ekonomi global menjadi faktor yang paling mempengaruhi kinerja perbankan di awal tahun (www.bisnis.com)

Kinerja bank dapat memberikan gambaran presentasi yang dicapai bank dalam operasionalnya, yang mana menggambarkan kondisi kesehatan keuangan perusahaan dengan indikator kecukupan modal, likuiditas dan profitabilitas. Dampak pandemi Covid-19 terhadap kinerja sektor perbankan, sungguh besar. Pembatasan sosial demi memutus mata rantai penularan Covid-19 telah membuat perekonomian lesu, nasabah yang akan bertransaksi dialihkan melalui $m$-banking, nasabah yang menerima kucuran kredit dari bank, tidak mampu membayar cicilan pokok dan bunganya, dalam arti menjadi kredit macet.

Kredit macet tersebut mempengaruhi pada perolehan laba bank, sebagaimana dapat dilihat dari laporan keuangan, setelah melakukan penelitian awal, diperoleh data bank yang mengalami penurunan pada pembukaan perdagangan harga saham tahun ini dengan data perdagangan saham akhir semester lalu.

Tabel 1. Penurunan Laba Selama 1 semester 2020

\begin{tabular}{|c|c|c|c|c|}
\hline No & $\begin{array}{c}\text { Bank } \\
\text { BUMN }\end{array}$ & $\begin{array}{c}\text { Presentase } \\
\text { Laba }\end{array}$ & $\begin{array}{c}\text { Bank } \\
\text { Swasta }\end{array}$ & $\begin{array}{c}\text { Presentase } \\
\text { Laba }\end{array}$ \\
\hline 1 & BNI & $41,60 \%$ & $\begin{array}{c}\text { CIMB } \\
\text { Niaga }\end{array}$ & $12,99 \%$ \\
\hline 2 & BTN & $40 \%$ & Danamon & $47,62 \%$ \\
\hline 3 & BRI & $37,04 \%$ & Panin & $11,46 \%$ \\
\hline 4 & Mandiri & $33,62 \%$ & BCA & $2,19 \%$ \\
\hline
\end{tabular}

Sumber : Kompasiana.com

Dilihat dari table 1.1 Bank Danamon mengalami penurunan laba paling banyak sebesar 47,62\% menjadi Rp. 845 Miliar dan Bank BNI mengalami penurunan $41,6 \%$ paling besar dibandingkan dengan beberapa Bank lainnya dan hanya membuka laba sebesar Rp. 4,460 Triliun ketika dibandingkan dengan semester 1 tahun 2019. Dalam penyaluran dan penghimpunan dana, bank BUMN harus bersaing dengan bank swasta, sehingga untuk dapat bertahan dalam persaingan dengan bank swasta, bank BUMN harus mampu menjaga likuiditas banknya dengan tetap memelihara kinerja keuangan bank.
Kesehatan suatu bank menjadi kepentingan pemilik dan pengelola bank, masyarakat pengguna jasa bank dan Bank Indonesia selaku pembina dan pengawas bank. Untuk menilai suatu kesehatan bank dapat dilihat dari berbagai segi. Penilaian ini bertujuan untuk menentukan apakah bank tersebut dalam kondisi yang sehat, cukup sehat, kurang sehat, atau tidak sehat. Dalam melakukan penilaian kesehatan bank telah ditentukan pemerintah melalui Bank Indonesia. Bank-bank diharuskan membuat laporan baik yang bersifat rutin maupun secara berkala mengenai seluruh aktivitasnya dalam suatu periode tertentu. Dari laporan ini dipelajari dan dianalisis, sehingga dapat diketahui kondisi kesehatannya akan memudahkan bank itu sendiri untuk memperbaiki kesehatannya. Menurut peraturan Bank Indonesia Nomor 13/1/PBI/2011 kinerja bank dapat diukur dengan pendekatan risiko, tata kelola perusahaan yang baik, rentabilitas dan pengelolaan modal yang mana dalam rasio disebutkan model RGEC.

Melihat betapa pentingnya dilakukannya suatu analisis kinerja keuangan berdasarkan laporan keuangannya, maka penulis bertujuan menganalisis kinerja keuangan Bank yang mengalami penurunan paling besar, sehingga mengetahui faktor apa yang harus diperbaiki pada kinerja bank semester berikutnya. Penelitian ini memiliki manfaat bagi peneliti khususnya yaitu sebagai salah satu media untuk mengetahui sejauh mana teori dengan praktik di lapangan saling berkesinambungan. Bagi objek penelitian ini dapat digunakan sebagai masukan dan bahan pertimbangan dalam mengetahui perubahan kinerja keuangan dan memprediksi keadaan perusahaan di masa yang akan datang.

Pada penelitian ini yang akan menjadi fokus pembahasan dalam profil risiko diantaranya pengukuran perbandingan banyaknya kredit dari bank terhadap penerimaan dana oleh bank diukur menggunakan rasio likuiditas. Sedangkan risiko kredit memegang peran penting dalam menjaga kestabilan keuangan bank yang dipengaruhi oleh kemampuan pemenuhan kewajiban sesuai perjanjian nasabah atau pihak lainnya kepada bank.

\section{TINJAUAN PUSTAKA}

\section{Kinerja Keuangan}

Kinerja keuangan Menurut Fahmi (2010 : 2) adalah suatu analisis yang dilakukan oleh suatu perusahaan untuk menilai sejauh mana suatu perusahaan telah melaksanakan dengan menggunakan aturan-aturan pelaksanaan keuangan secara baik dan benar. Seperti dengan membuat suatu laporan keuangan yang telah memenuhi standar dan ketentuan dalam SAK (Standar Akuntansi Keuangan) atau GAAP 
(Generally Accepted Accounting Principle), dan lainnya.

\section{Kesehatan Bank}

Kesehatan bank dalam peraturan yang dikeluarkan Bank Indonesia tahun 2007, dapat diartikan sebagai kemampuan bank untuk melakukan kegiatan operasional perbankan secara normal dan mampu memenuhi semua kewajibannya dengan baik dengan cara yang sesuai peraturan perbankan yang berlaku. Pengertian ini merupakan batasan yang sangat luas karena kesehatan bank memang mencakup kesehatan suatu bank untuk melaksanakan seluruh kegiatan usaha perbankannya. Kegiatan tersebut meliputi:

1. Kemampuan menghimpun dana dari masyarakat, lembaga lain, dan modal sendiri,

2. Kemampuan mengelola dana,

3. Kemampuan untuk menyalurkan dana kepada masyarakat,

4. Kemampuan memenuhi kewajiban pada masyarakat, karyawan, pemilik modal, dan pihak lain,

5. Pemenuhan peraturan perbankan yang berlaku.

\section{Analisis Rasio Keuangan}

Menurut Arthur (2011:74) membantu kita untuk mengidentifikasikan beberapa kelemahan dan kekuatan keuangan perusahaan. Rasio memberikan dua cara bagaimana membuat perbandingan dan data keuangan perusahaan yang berarti. Kita dapat meneliti perbandingan rasio antar waktu untuk meneliti arah pergerakannya dan kita dapat membandingkan rasio perusahaan dengan rasio perusahaan lainnya. Tujuan dari penggunaan suatu rasio saat menganalisis informasi yang akan dianalisis agar rasio dari dua perusahaan yang berbeda dapat dibandingkan atau juga suatu perusahaan dengan batas-batas waktu yang berbeda.

\section{Indikator Kinerja Bank Menggunakan RGEC}

Indikator Kesehatan Bank Menggunakan Metode RGEC, yaitu :

\section{a. Risk Profile (Profil Risiko)}

Profil risiko (risk profile) merupakan penilaian terhadap risiko inheren dan kualitas penerapan manajemen risiko dalam operasional bank yang dilakukan terhadap 8 risiko, yaitu: risiko kredit, risiko pasar, risiko likuiditas, risiko operasional, risiko hukum, risiko stratejik, risiko kepatuhan, dan risiko reputasi. Risiko inheren adalah risiko yang melekat dengan kegiatan bisnis bank, baik yang dapat dikuantifikasi maupun tidak dapat dikuantifikasi, yang berpotensi dapat mempengaruhi posisi keuangan bank. Inherent risk dapat berupa parameter yang bersifat ex-post (telah terjadi) maupun parameter yang bersifat ex-ante (belum terjadi).

\section{b. Good Corporate Governance}

Corporate Governance atau tata kelola perusahaan yang digunakan dalam mengarahkan dan mengendalikan kegiatan bisnis suatu perusahaan. Corporate governance juga dapat diartikan sebagai hubungan antara dewan komisaris, dewan direksi, stakeholders, dan pemegang saham perusahaan. Berdasarkan peraturan Bank Indonesia No 13/1/2011 yang mewajibkan bank-bank di indonesia memasukan faktor Good Corporate Governance ke dalam salah satu penilaian tingkat kesehatan bank, maka perusahaan dirasa sangat perlu untuk memiliki tanggung jawab yang besar dalam menjaga stabilitas sistem perbankan sehingga dapat memperoleh predikat penerapan tata kelola perusahaan yang sehat (Good Corporate Governance). Good Corporate Governance adalah suatu tata kelola yang menerapkan prinsip-prinsip keterbukaan, akuntabilitas, pertanggungjawaban, profesional, dan kewajaran.

\section{c. Rentabilitas}

Rentabilitas merupakan aspek yang digunakan untuk mengukur kemampuan bank dalam meningkatkan keuntungan. Kemampuan ini dilakukan dalam suatu periode. Kegunaan aspek ini juga untuk mengukur tingkat efisiensi usaha dan profitabilitas yang dicapai oleh bank yang bersangkutan. Bank yang sehat adalah bank yang diukur secara rentabilitas yang terus meningkat diatas standar yang telah ditetapkan. Penilaian ini meliputi hal-hal seperti:

1) Rasio laba terhadap Total Aset (ROA),

2) Rasio laba terhadap Modal sendiri (ROE), dan

3) Pendapatan operasi bersih terhadap Aktiva produktif (NOM).

\section{d. Permodalan}

Dalam aspek ini yang dinilai adalah permodalan yang dimiliki oleh bank yang didasarkan kepada kewajiban penyediaan modal minimum bank. Penilaian tersebut didasarkan oleh CAR (Capital Adequacy Ratio) yang telah ditetapkan BI. Perbandingan rasio CAR adalah rasio modal terhadap Aktiva Tertimbang Menurut Risiko (ATMR).

Penelitian kinerja keuangan cukup banyak dilakukan para akademisi dan peneliti. Dalam penelitian yang dilakukan oleh Dikdik \& Bambang (2013) dengan judul faktor-faktor yang mempengaruhi kinerja bank pada industri perbankkan di Bursa Efek Indonesia menjelaskan bahwa variabel BOPO dan NPL 
berpengaruh negatif signifikan terhadap ROA. Sedangkan dalam penelitian yang dilakukan oleh Sabir (2012) dengan judul Pengaruh rasio kesehatan bank terhadap kinerja keuangan bank umum Syariah dan bank konvensional di Indonesia menyatakan bahwa NOM dan FDR berpengaruh positif dan signifikan terhadap ROA pada Bank Umum Syariah di Indonesia. Untuk Bank Konvensional BOPO dan NPL tidak berpengaruh terhadap ROA. Mengukur dari hasil penelitian sebelumnya pada bank konvensional, maka penulis menarik untuk melakukan penelitian Analisis rasio keuangan terhadap kinerja Bank Konvensional yang terdaftar di Bursa Efek Indonesia.

\section{METODE PENELITIAN}

Analisis data adalah upaya atau cara untuk mengolah data menjadi informasi sehingga karakteristik data tersebut bisa dipahami dan bermanfaat untuk solusi permasalahan, terutama masalah yang berkaitan dengan penelitian. Atau definisi lain dari analisis lain dari analisis data yakni kegiatan yang dilakukan untuk mengubah data hasil dari penelitian menjadi informasi yang nantinya bisa dipergunakan dalam mengambil kesimpulan.

Statistik deskriptif adalah statistik yang digunakan untuk menganalisis data dengan cara mendeskripsikan atau menggambarkan data yang telah terkumpul. Statistik inferensial menggunakan model statistik untuk membantu kita membandingkan data sampel dengan sampel lain atau dengan penelitian sebelumnya. Populasi dalam penelitian ini adalah perusahaan perbankkan yang telah go public di Bursa Efek Indonesia, dari populasi itu di tariklah sampel menggunakan Teknik sampel purposive dengan kriteria penarikan sampel:

1. Perusahaan perbankkan konvensional yang terdaftar di Bursa Efek Indonesia

2. Konsistensi melaporkan data keuangan selama periode penelitian

3. Perusahaan yang mengalami penurunan laba selama periode penelitian

Setelah melakukan uji kriteria awal, dalam penelitian ini akan menggunakan empat objek penelitian pada PT. Bank Negara Indonesia, Tbk PT Bank Mandiri, Tbk PT Bank CIMB Niaga, Tbk dan PT Bank BCA, Tbk untuk menganalisis rasio keuangan bank pada periode 2015- 2020.

\section{HASIL DAN PEMBAHASAN PENELITIAN}

\section{Analisis RGEC}

Ke empat bank yang diteliti mempublikasikan laporan annual report secara go public melalui idx.co.id, semua data perhitungan dalam penelitian ini mengacu kepada data keuangan yang dilaporkan oleh perusahaan. Pembahasan hasil analisis menilai tingkat kesehatan bank dengan metode RGEC yang berdasarkan surat edaran Bank Indonesia no 13/24/DPN/2011.

\section{Risk Profile}

Pada penelitian ini nilai resiko diukur menggunakan rasio LDR dan NPL yang sudah dibuat dalam presentasi hasil perhitungannya, kemudian di analisis dengan membandingkan bobot peringkat hasil hitung dengan aturan Bank Indonesia.

Tabel 2 Bobot Peringkat Komposit Komponen NPL

\begin{tabular}{|c|c|c|}
\hline PK & Bobot $\%$ & Keterangan \\
\hline $\mathbf{1}$ & Kurang dari 2 & Sangat sehat \\
\hline $\mathbf{2}$ & $2-3,5$ & Sehat \\
\hline $\mathbf{3}$ & $3,5-5$ & Cukup sehat \\
\hline $\mathbf{4}$ & $5-8$ & Kurang sehat \\
\hline $\mathbf{5}$ & Lebih dari 8 & Tidak sehat \\
\hline
\end{tabular}

Sumber : SE Bank Indonesia No.13/24/DPNP/2011 
Tabel 3 Hasil Pembobotan Bank nilai rasio NPL

\begin{tabular}{|c|c|c|c|c|c|c|}
\hline Bank & Periode & $\begin{array}{c}\text { NPL } \\
\text { BRUTO\% }\end{array}$ & Peringkat & $\begin{array}{l}\text { NPLNETTO } \\
\%\end{array}$ & Peringkat & Keterangan \\
\hline \multirow{5}{*}{ BNI } & 2015 & 2.3 & 2 & 1.2 & 1 & sehat \\
\hline & 2016 & 1.9 & 1 & 0.8 & 1 & sangat sehat \\
\hline & 2017 & 23 & 2 & 0.7 & 1 & sehat \\
\hline & 2018 & 3 & 2 & 0.4 & 1 & sehat \\
\hline & 2019 & 2.7 & 2 & 0.9 & 1 & sehat \\
\hline \multirow{5}{*}{ MANDIRI } & 2015 & 239 & 2 & 0.84 & 1 & sehat \\
\hline & 2016 & 279 & 2 & 0.67 & 1 & sehat \\
\hline & 2017 & 3.45 & 2 & 1.06 & 1 & sehat \\
\hline & 2018 & 3.96 & 2 & 1.38 & 1 & sehat \\
\hline & 2019 & 229 & 2 & 0.6 & 1 & sehat \\
\hline \multirow{5}{*}{$\begin{array}{c}\text { CIMB } \\
\text { NIAGA }\end{array}$} & 2015 & 2.42 & 2 & 1.3 & 1 & sehat \\
\hline & 2016 & 2.64 & 2 & 1.55 & 1 & sehat \\
\hline & 2017 & 3.13 & 2 & 2.16 & 2 & sehat \\
\hline & 2018 & 3.41 & 2 & 2.16 & 2 & sehat \\
\hline & 2019 & 3.35 & 2 & 1.59 & 1 & sehat \\
\hline \multirow{5}{*}{ BCA } & 2015 & 1.3 & 1 & 0.5 & 1 & sangat sehat \\
\hline & 2016 & 1.4 & 1 & 0.4 & 1 & sangat sehat \\
\hline & 2017 & 1.5 & 1 & 0.4 & 1 & sangat sehat \\
\hline & 2018 & 1.3 & 1 & 0.3 & 1 & sangat sehat \\
\hline & 2019 & 0.7 & 1 & 0.2 & 1 & sangat sehat \\
\hline
\end{tabular}

Sumber : Hasil Pengolahan peneliti (2021)

Berdasarkan Tabel 3, Bank BNI pada tahun 2016 berada pada posisi sangat sehat tergambarkan dari hasil perhitungan selalu berada pada posisi kurang dari 2 baik itu secara perhitungan netto $0.8 \%$ maupun bruto $1.9 \%$. Bank Mandiri dan Bank CIMB Niaga berada pada posisi 2 yang mana masuk kedalam kategori sehat selama periode penelitian dilakukan, dan yang terakhir adalah Bank BCA selama lima periode penelitian secara konsisten berada pada posisi sangat sehat baik itu dihitung dari neto ataupun bersih. Hal ini sesuai dengan teori yang mana semakin kecil resiko yang disebabkan maka nilai rasio NPL pun akan kecil. Secara stagnan perbankkan mampu mengatur NPL sehingga kredit menjadi rendah meski di lapangan dihadapkan dengan faktor pertumbuhan ekonomi global.

Risk Profil dapat juga dianalisis menggunakan rasio LDR, yang mana mengukur total kredit di bagi dana pihak ketiga

\section{Tabel 4. Bobot Peringkat Komposit Komponen} LDR

\begin{tabular}{|c|c|c|}
\hline PK & Bobot \% & Keterangan \\
\hline $\mathbf{1}$ & $60-<70$ & Sangat sehat \\
\hline $\mathbf{2}$ & $70-<85$ & Sehat \\
\hline $\mathbf{3}$ & $85-<100$ & Cukup sehat \\
\hline $\mathbf{4}$ & $100-<120$ & Kurang sehat \\
\hline $\mathbf{5}$ & $>120: 60$ & Tidak sehat \\
\hline
\end{tabular}

Sumber : SE Bank Indonesia No 13/24/DPNP/2011
Tabel 5 Hasil Pembobotan Bank nilai rasio LDR

\begin{tabular}{|c|c|c|c|c|}
\hline Bank & Periode & LDR \% & Peringkat & Keterangan \\
\hline \multirow{5}{*}{ BNI } & 2015 & 91.5 & 3 & Cukup Sehat \\
\hline & 2016 & 88.8 & 3 & Cukup Sehat \\
\hline & 2017 & 85.6 & 3 & Cukup Sehat \\
\hline & 2018 & 90.4 & 3 & Cukup Sehat \\
\hline & 2019 & 87.8 & 3 & Cukup Sehat \\
\hline \multirow{5}{*}{ MANDIRI } & 2015 & 80.15 & 2 & Sehat \\
\hline & 2016 & 81.6 & 2 & Sehat \\
\hline & 2017 & 78.2 & 2 & Sehat \\
\hline & 2018 & 77.1 & 2 & Sehat \\
\hline & 2019 & 81.1 & 2 & Sehat \\
\hline \multirow{5}{*}{$\begin{array}{c}\text { CIMB } \\
\text { NIAGA }\end{array}$} & 2015 & 97.75 & 3 & Cukup Sehat \\
\hline & 2016 & 97.18 & 3 & cukupcSehat \\
\hline & 2017 & 96.24 & 3 & Cukup Sehat \\
\hline & 2018 & 98.38 & 3 & Cukup Sehat \\
\hline & 2019 & 97.98 & 3 & Cukup Sehat \\
\hline \multirow{5}{*}{ BCA } & 2015 & 80.5 & 2 & Sehat \\
\hline & 2016 & 81.6 & 2 & Sehat \\
\hline & 2017 & 78.2 & 2 & Sehat \\
\hline & 2018 & 77.1 & 2 & Sehat \\
\hline & 2019 & 81.1 & 2 & Sehat \\
\hline
\end{tabular}

Sumber : Hasil Pengolahan Peneliti (2021)

Berdasarkan tabel 5 Persentase hasil perhitungan LDR semakin tinggi nilainya akan berakibat pada rendahnya tingkat likuiditas bank, maka bank harus meningkatkan dana pihak ketiganya untuk menutupi kredit yang diberikan oleh pihak bank, bisa juga dengan mengurangi pemberian kredit. Di atas Bank BNI dan Bank CIMB Niaga berada pada posisi cukup sehat yang mana nilai rasio LDR 2 bank ini posisinya lebih besar dibandingkan Bank Mandiri dan Bank BCA.

\section{Good Corporate Governance (GCG)}

Bank Indonesia telah menetapkan peraturan Good Corporate Governance (GCG) menggunakan peringkat komposit $G C G$ dalam SE No 15/15/DPNP mengenai pelaksanaan GCG bank Umum, manajemen memastikan menerapkan lima prinsip dasar yang harus dilakukan bank secara profesional, dengan melakukan penilaian sendiri secara berkala minimal setiap semester untuk posisi akhir bulan juni dan desember. Faktor yang nilainya yaitu pelaksanaan tugas dan tanggung jawab direksi, pelaksanaan tugas dan tanggung jawab dewan komisaris, penanganan benturan kepentingan, kelengkapan dan pelaksanaan tugas komite, penerapan fungsi audit intern, penerapan fungsi kepatuhan, penerapan manajemen risiko termasuk sistem pengendalian intern, penerapan fungsi audit ekstern, transparansi kondisi keuangan dan nonkeuangan bank, penyedia dana pada pihak terkait dan penyedia dana besar, rencana strategis bank dan laporan pelaksanaan GCG dan pelaporan internal. 
Untuk menganalisis GCG suatu perbankkan peneliti memperoleh dari laporan keuangan annual report tahunan yang sudah perusahaan laporkan pada bursa.

- Bank BNI, Tbk telah melakukan penilaian sendiri atas pelaksanaan GCG berdasarkan peraturan yang dikeluarkan oleh Otoritas Jasa Keuangan No. 55/POJK.03/2016 tentang penerapan tata kelola bagi Bank Umum yang mengukur pelaksanaan GCG nilai Komposit berada pada peringkat 2 yaitu $1,50>$ - nilai komposit <2,50, Hal ini menunjukkan manajemen Bank telah melakukan penerapan tata kelola secara umum dengan baik. Terlihat dari pemenuhan yang memadai atas prinsip dasar tata kelola umum, Perbankkan kedepannya harus meningkatkan seperisi unit compliance dalam menekan frekuensi dan nominal denda dari regulator, dalam peningkatan pemahaman SOP oleh segenap pegawai maka Bank mewajibkan segenap pegawai untuk meningkatkan awareness melalui e-learning mandatory sehingga kesalahan yang diakibatkan human error dapat ditekan pada setiap tahunnya.

- Bank Mandiri, Tbk, dalam melaksanakan GCG dalam kurun waktu 14 tahun telah mendapatkan predikat sangat terpercaya, pada periode penelitian Bank Mandiri memiliki nilai tertinggi dibandingkan perusahaan peserta lainnya berdasarkan penilaian corporate governance \& perception index yaitu sebesar 94,9\% meningkat dari skor sebelumnya $94,8 \%$.

- Bank CIMB Niaga, Tbk telah melakukan penilaian sendiri dengan melihat kepada ketentuan POJK NO 55/POJK.03/2016 dan SEOJK No. 13/POJK.03/2017 secara komprehensif dan terstruktur menjadi 3 aspek tata kelola yaitu : Struktur Tata kelola, proses tata kelola dan hasil tata kelola. Berdasarkan ketiga aspek ini hasil penilaian berada pada posisi 2 yang mana masuk kedalam kategori baik yang mencerminkan secara umum manajemen bank dan anak perusahaan telah melakukan penerapan prinsip-prinsip tata kelola yang memadai.

- Bank BCA, Tbk telah melaksanakan tata kelola perusahaan yang baik mengacu kepada ketentuan regulator, ketentuan internal, dan best practices yang berlaku dan diteladani dalam skala nasional maupun internasional.

\section{Earning}

Pada analisis pendapatan peneliti menggunakan dua rasio dalam penilaian tingkat kesehatan bank yaitu ROA yang mana rasio ini membandingkan laba sesudah pajak dengan total asset yang dimiliki oleh perusahaan, pada saat perusahaan memiliki return yang kinerja perusahaan dapat dimasukkan kedalam kategori kinerja yang baik. Sedangkan untuk membandingkan antara pendapatan bunga bersih kepada aktiva produktif menggunakan rasio NIM, yang mana rasio ini mampu menggambarkan kinerja bank dalam menghasilkan pendapatan bunga, pendapatan bunga ini harus diputar kembali menjadi modal bagi bank. Bobot penilaian komposit rasio adalah

Tabel 6. Bobot Peringkat Komposit Komponen ROA \& NIM

\begin{tabular}{|c|c|c|c|c|}
\hline PK & \multicolumn{1}{|c|}{$\begin{array}{c}\text { Robot } \\
\text { ROA } \%\end{array}$} & Keterangan & Bobot NIM\% & Keterangan \\
\hline $\mathbf{1}$ & $>2$ & Sangat sehat & $>5$ & Sangat sehat \\
\hline $\mathbf{2}$ & $1,25-2$ & Sehat & $2.01-5$ & Sehat \\
\hline $\mathbf{3}$ & $0,5-1,25$ & Cukup sehat & $1,5-2,00$ & Cukup sehat \\
\hline $\mathbf{4}$ & $0-0,5$ & Kurang sehat & $0-1,49$ & $\begin{array}{c}\text { Kurang } \\
\text { sehat }\end{array}$ \\
\hline $\mathbf{5}$ & Negatif & Tidak sehat & Negatif & Tidak sehat \\
\hline
\end{tabular}

Sumber : SE Bank Indonesia No. 13/24/DPNP/2011

Hasil analisis rasio ROA dan NIM pada bank BNI, Bank CIMB Niaga, Bank Mandiri dan Bank BCA ini dapat dilihat pada Tabel di bawah ini :

Tabel 7. Nilai Rasio ROA dan NIM

\begin{tabular}{|c|c|c|c|c|}
\hline Bank & Periode & ROA \% & Peringkat & Keterangan \\
\hline \multirow{5}{*}{ BNI } & 2015 & 2.4 & 1 & Sangat Sehat \\
\hline & 2016 & 2.8 & 1 & Sangat Sehat \\
\hline & 2017 & 2.7 & 1 & Sangat Sehat \\
\hline & 2018 & 2.7 & 1 & Sangat Sehat \\
\hline & 2019 & 2.6 & 1 & Sangat Sehat \\
\hline \multirow{5}{*}{ MANDIRI } & 2015 & 3.03 & 1 & Sangat Sehat \\
\hline & 2016 & 3.17 & 1 & Sangat Sehat \\
\hline & 2017 & 2.72 & 1 & Sangat Sehat \\
\hline & 2018 & 1.95 & 2 & Sehat \\
\hline & 2019 & 3.15 & 1 & Sangat Sehat \\
\hline \multirow{5}{*}{$\begin{array}{l}\text { CIMB } \\
\text { NIAGA }\end{array}$} & 2015 & 1.99 & 2 & Sehat \\
\hline & 2016 & 1.85 & 2 & Sehat \\
\hline & 2017 & 1.7 & 2 & Sehat \\
\hline & 2018 & 1.09 & 2 & Sehat \\
\hline & 2019 & 0.47 & 3 & Cukup Sehat \\
\hline \multirow{5}{*}{$\mathbf{B C A}$} & 2015 & 4 & 1 & Sangat Sehat \\
\hline & 2016 & 4 & 1 & Sangat Sehat \\
\hline & 2017 & 3.9 & 1 & Sangat Sehat \\
\hline & 2018 & 4 & 1 & Sangat Sehat \\
\hline & 2019 & 3.8 & 1 & Sangat Sehat \\
\hline Bank & Periode & NIM \% & Peringkat & Keterangan \\
\hline \multirow{5}{*}{ BNI } & 2015 & 4.9 & 2 & Sehat \\
\hline & 2016 & 5.3 & 1 & Sangat Sehat \\
\hline & 2017 & 5.5 & 1 & Sangat Sehat \\
\hline & 2018 & 6.2 & 1 & Sangat Sehat \\
\hline & 2019 & 6.4 & 1 & Sangat Sehat \\
\hline \multirow{5}{*}{ MANDIRI } & 2015 & 5.46 & 1 & Sangat Sehat \\
\hline & 2016 & 5.52 & 1 & Sangat Sehat \\
\hline & 2017 & 5.63 & 1 & Sangat Sehat \\
\hline & 2018 & 6.29 & 1 & Sangat Sehat \\
\hline & 2019 & 5.9 & 1 & Sangat Sehat \\
\hline \multirow{5}{*}{$\begin{array}{l}\text { CIMB } \\
\text { NIAGA }\end{array}$} & 2015 & 5.31 & 1 & Sangat Sehat \\
\hline & 2016 & 5.12 & 1 & Sangat Sehat \\
\hline & 2017 & 5.6 & 1 & Sangat Sehat \\
\hline & 2018 & 5.64 & 1 & Sangat Sehat \\
\hline & 2019 & 5.21 & 1 & Sangat Sehat \\
\hline \multirow{5}{*}{ BCA } & 2015 & 62.2 & 1 & Sangat Sehat \\
\hline & 2016 & 6.1 & 1 & Sangat Sehat \\
\hline & 2017 & 6.2 & 1 & Sangat Sehat \\
\hline & 2018 & 6.8 & 1 & Sangat Sehat \\
\hline & 2019 & 6.7 & 1 & Sangat Sehat \\
\hline
\end{tabular}

Sumber : Hasil Pengolahan Penulis 
Berdasarkan Tabel 7 selama periode penelitian Bank BNI, bank Mandiri dan Bank BCA masuk kedalam kategori sangat sehat. Untuk bank CIMB Niaga pada tahun 2019 pada sisi rasio ROA mengalami penurunan sebesar $0,47 \%$ dimana nilai returnnya lebih besar dibandingkan tahun sebelumnya. Pada rasio NIM selama periode penelitian Bank BNI, Bank Mandiri, Bank CIMB Niaga dan Bank BCA mendapatkan nilai komposit sama yaitu 1 yang mana hasil perhitungan rasionya memiliki hasil lebih dari lima. Hasil perhitungan ini menunjukkan bahwa kinerja bank selama 2015-2019 sangat baik dalam menghadapi kredit bermasalah.

\section{Capital}

Analisis capital dilakukan untuk melihat seberapa besar aktiva yang dihasilkan perbankkan mengandung unsur risiko kredit baik itu dari penyertaan surat berharga tagihan piutang dengan membandingkan pada modal yang dimiliki oleh bank sendiri sebelum adanya tambahan modal dari pihak ketiga. Hasil analisis Rasio CAR dapat dilihat pada tabel dibawah ini

\section{Tabel 8. Hasil Analisis Rasio CAR}

\begin{tabular}{|c|c|c|c|c|}
\hline Bank & Periode & CAR \% & Peringkat & Keterangan \\
\hline \multirow{5}{*}{ BNI } & 2015 & 19.73 & 1 & Sangat Sehat \\
\hline & 2016 & 18.5 & 1 & Sangat Sehat \\
\hline & 2017 & 18.5 & 1 & Sangat Sehat \\
\hline & 2018 & 19.4 & 1 & Sangat Sehat \\
\hline & 2019 & 19.5 & 1 & Sangat Sehat \\
\hline \multirow{5}{*}{ MANDIRI } & 2015 & 22.09 & 1 & Sangat Sehat \\
\hline & 2016 & 21.14 & 1 & Sangat Sehat \\
\hline & 2017 & 22.06 & 1 & Sangat Sehat \\
\hline & 2018 & 21.42 & 1 & Sangat Sehat \\
\hline & 2019 & 18.63 & 1 & Sangat Sehat \\
\hline \multirow{5}{*}{$\begin{array}{c}\text { CIMB } \\
\text { NIAGA }\end{array}$} & 2015 & 21.47 & 1 & Sangat Sehat \\
\hline & 2016 & 19.66 & 1 & Sangat Sehat \\
\hline & 2017 & 18.6 & 1 & Sangat Sehat \\
\hline & 2018 & 17.96 & 1 & Sangat Sehat \\
\hline & 2019 & 16.28 & 1 & Sangat Sehat \\
\hline \multirow{5}{*}{ BCA } & 2015 & 23.8 & 1 & Sangat Sehat \\
\hline & 2016 & 23.4 & 1 & Sangat Sehat \\
\hline & 2017 & 23.1 & 1 & Sangat Sehat \\
\hline & 2018 & 21.9 & 1 & Sangat Sehat \\
\hline & 2019 & 18.7 & 1 & Sangat Sehat \\
\hline
\end{tabular}

Sumber : Hasil Pengolahan Peneliti (2021)

Berdasarkan Tabel 8, diketahui nilai CAR bank BNI, Bank Mandiri, Bank CIMB Niaga dan Bank BCA selama periode 2015-2019 memperoleh peringkat 1 secara konsisten. Hasil ini menunjukkan bahwa Bank yang dijadikan objek penelitian mampu mengatasi resiko yang diakibatkan dari aset secara baik, melihat nilai Car yang tinggi maka memberikan dampak yang baik untuk perbankkan.

\section{SIMPULAN DAN SARAN}

\section{Simpulan}

Secara keseluruhan analisis kinerja keuangan menggunakan model RGEC dengan nilai rerata setiap rasionya dinyatakan dalam keadaan sehat, membuktikan bahwa Bank BNI, Bank Mandiri, Bank CIMB Niaga dan Bank BCA pada periode 2015-2019 berada pada predikat keadaan baik. Pada sisi Likuiditas yang dihitung menggunakan rasio LDR memberikan gambaran bahwa bank yang dijadikan objek penelitian berada pada posisi sehat untuk Bank Mandiri dan BCA hal ini sesuai dengan studi awal yang mana kedua Bank ini meskipun mengalami penurunan laba mampu tetap mempertahankan kinerja kesehatan bank. Pada penilaian GCG Bank BNI dan Bank BCA hal ini menunjukkan telah menerapkan tata kelola sesuai dengan aturan dari otoritas jasa keuangan.

\section{Saran}

Untuk peneliti selanjutnya yang tertarik dalam tema kesehatan bank, dapat ditambahkan variabel harga saham untuk perbankkan yang sudah go public. Objek penelitian bisa dibandingkan Antara bank konvensional dengan bank syariah, karena kedua bank ini memiliki tata aturan yang berbeda dalam pengelolaan keuangannya.

\section{DAFTAR PUSTAKA}

Bank Indonesia,Peraturan Bank Indonesia Nomor 13/1/PBI/2011 tanggal 05 Januari 2011 "Perihal Tatacara Penilaian Tingkat Kesehatan Bank Umum.

Bank Indonesia, Peraturan Bank Indonesia Nomor: 13/27/PBI/2011 tanggal 28 Desember 2011 Tentang Perubahan Atas Peraturan Bank Indonesia No. 11/1/PBI/2009 Tentang Bank Umum.

Bank Indonesia, 2007 Peraturan Bank Indonesia nomor 9/1/PBI/2007 Tentang Sistem Penilaian Tingkat Kesehatan Bank Umum Berdasarkan Sistem Syariah.

Dikdik, Bambang, 2013 "Faktor-Faktor yang Mempengaruhi Kinerja Bank (studi Empirik Pada Industri Perbankan di Bursa Efek Indonesia" Jurnal Bisnis dan Ekonomi (JBE), Edisi Maret Hal 25-39

Erthur, John, dkk. 2011 “ Manajemen Keuangan : Prinsip dan Penerapan” Edisi 10 PT Indeks

Khaerul Usman, Manajemen Perbankan Syariah, (Bandung: CV Pustaka Setia, 2013) 
490 Coopetition, Vol 12, Nomor XII, November 2021, (E-ISSN : 2615-4978, P-ISSN : 2086-4620)

Khisti Minarrohmah; Fransisca Yaningwati; dan Firdausi Nuzula, Analisis Tingkat Kesehatan Bank dengan Menggunakan Pendekatan RGEC (Risk Profile, Good Corporate Governance, Earning, Capital), (Jurnal Administrasi Bisnis, Volume 17, Nomer 1, Desember 2014)

Irham Fahmi, "Analisis Kinerja Keuangan" (Bandung: Alfabet, 2010)

Sabir, 2012 "Pengaruh Rasio Kesehatan Bank Terhadap kinerja Keuangan Bank Umum Syariah dan Bank Konvensional Di Indonesia", Jurnal Analisis Edisi Juni Vol 1 : 79-86

$\underline{w w w . i d x . c o . i d}$ 